\title{
Testing for Competition in Serbian Banking Industry: the Panzar-Rosse Approach
}

\author{
Article history: \\ Received: 29 January 2015 \\ Sent for revision: 17 February 2015 \\ Received in revised form: 2 July 2015 \\ Accepted: 3 July 2015 \\ Available online: 15 October 2015
}

\begin{abstract}
The level of competitiveness in Serbian banking industry is tested using the Panzar-Rosse model on bank level data in period from 2004 to 2012. The panel estimation results imply monopolistic competition in the entire banking sector. However when the methodology is applied to the subset of the large banks, which comprise more than $65 \%$ of total banking sector assets, we find that they exhibit monopoly or strong oligopoly behaviour with perfect collusion. This implies that the prices of the banking products are suboptimal in terms of general welfare.
\end{abstract}

Keywords: Panzar-Rosse test; competition; banking industry

\section{Testiranje konkurencije u bankarskom sektoru Srbije: Panzar-Rosse pristup}

Apstrakt: Rad ispituje konkurenciju u bankarskom sektoru Srbije pomoću Panzar-Rosse modela koji je ocenjen za panel banaka u periodu 2004-2012. Rezultati ukazuju na prisustvo monopolističke konkurencije na nivou celog

\footnotetext{
${ }^{1}$ SAS Institute Adriatic Region, Belgrade, Serbia, aljosa.babic@sas.com

${ }^{2}$ National Bank of Serbia, Belgrade, Serbia

${ }^{3}$ University of Belgrade, Faculty of Economics, Serbia

The views expressed in the paper are those of the authors and do not necessarily represent the official view of the National Bank of Serbia and SAS Institute. The authors thank Milan Nedeljković and two anonymous referees for useful comments and suggestions.
} 
Babić A. et al.: Testing for Competition in Serbian Banking Industry: the...

bankarskog sektora. Ocene na podskupu velikih banaka, koje čine 65\% ukupne aktive bankarskog sektora, ukazuju na monopolsko ponašanje ili jaku nekonkurentsku oligopolsku strukturu. To znači da su cene bankarskih proizvoda suboptimalne posmatrano sa aspekta opšteg blagostanja.

Ključne reči: Panzar-Rosse test; konkurencija; bankarski sektor

\section{Introduction}

The current financial and economic crisis has highlighted the crucial position of banks in the economy. Maintaining a stable financial system is of utmost importance for a country. Banks as financial intermediaries also play an important role in the transmission of monetary policy, the provision of credit and in the payment system.

Important influence of banking competition on the economy has been emphasized in both theoretical and economic policy literature. Banking competition impacts the interest rate pass-through as in more competitive markets bank interest rates respond more strongly to the changes in market rates (see Bikker et al. 2011, Bruna, 2008). The issues also widely discussed in the literature are whether the banking competition improves or reduces stability of financial system (see e.g. Smith, 1998; Allen and Gale, 2004; De Jonghe and Vander Vennet, 2008; Schaeck et al. 2009) or productive efficiency (Berger and Hannan, 1998; Maudos and De Guevara, 2007). Moreover, a number of empirical studies finds a strong relation between banking market structure and economic growth (see e.g. Jayaratne and Strahan, 1996; Levine et al. 2000; Collender and Shaffer, 2003 and Botric and Slijepcevic, 2007). Thus, the competition in banking industry is important for maintaining the stability of both financial and real sector. The importance of the analysis is supported by on-going changes of global banking regulation (introduction of new Basel accord, changes in EU banking regulation) and the continuous development of information technology which both have a serious impact on banking competition and concentration.

A vast literature that analyses the competition in banking industry has been developed in two main directions. The first strand uses structural approach, which relies on the Structure-Conduct-Performance paradigm (SCP) and the efficiency hypothesis. The idea of this approach is to provide a link between market concentration and market competition, i.e. to investigate whether a high market concentration causes collusive behaviour among large banks 
Babić A. et al.: Testing for Competition in Serbian Banking Industry: the...

leading to outstanding market performance ${ }^{4}$. Here, the competition is proxied by measures of banking concentration, such as concentration indices or Herfindahl-Hirschman index $(\mathrm{HHI})$, for example. However, the empirical literature has shown that the relationship between competition and concentration is not straightforward one (see e.g. Shaffer, 1993, 1999, 2002, Shaffer and DiSalvo 1994, Claessens and Laeven 2004). Namely, the conduct may be less competitive than the concentration measures would suggest. ${ }^{5}$ On the other hand, it is also possible that the competition would be much stronger than the concentration measures suggested if the few large banks competed for the market share. As the mismatch can run in both directions, concentration presents an extremely unreliable measure of performance.

Motivated by the drawbacks of structural models, the second strand of the literature uses non-structural approach. The methods assess competition along the lines of the new empirical industrial organization literature. The main advantage relative to more heuristic approaches is that the models can be formally derived from profit-maximizing equilibrium conditions. This approach is, therefore, based on testing the competitiveness and the use of market power of banks, without the presence of structural measures and ignoring the market concentration. As it is of interest for the present paper to study competition in Serbia's banking sector, which is not highly concentrated, this approach seems to be better suited for the analysis (for the analysis of Serbian banking industry using concentration indices see Miljkovic et al. 2013 or Ljumovic et al. 2014).

The empirical literature widely uses the Panzar-Rosse model (Panzar and Rosse, 1987) to examine implications of non-structural approach. ${ }^{\circ}$ The idea is to estimate a reduced-form equation relating gross revenue to a vector of input prices and other control variables. The associated measure of competition - usually called the $\mathrm{H}$ statistic - is obtained as the sum of elasticities of gross revenue with respect to input prices. Bikker and Haaf (2002) apply the statistics to measure the level of competition in 23 highincome countries, Bikker and Spierdijk (2008) to examine the evolution of competition over time for the sample of 101 countries, Weill (2013) to affirm the improvement of competition in EU countries in 2000s, among others. A

4 The efficiency hypothesis suggests that the results in performance are due to efficiency of large market players, banks in this case.

5 If, for example, market consists of four large banks around 15\% of total banking sector assets each, and large number of small banks value of $\mathrm{HHI}$ will still be low. Low concentration does not always lead to increase in competition, as small number of large market participants has incentives to collude.

${ }^{6}$ In this strand of literature, alternative models are Iwata (1974) and Bresnahan (1989). 
Babić A. et al.: Testing for Competition in Serbian Banking Industry: the...

number of researchers measured the competition of banking sector for single country, such as De Rozas (2007) for Spanish banking industry, Macit (2012) for Italian, as well as Matthews et al (2006) for a subset of the largest banks in British banking industry. Majority of these studies found that banks operate in industry characterized by monopolistic competition. These findings are in line with the expectations, once product differentiation is taken into account. However, as Bikker et al. (2012) have recently showed, the results may be influenced by misspecification of revenue function as scaled function distinguishes between perfect and imperfect competition and thus fails as a test for market power. Their findings suggest a positive bias in the value of $\mathrm{H}$ statistic estimated based on the scaled revenue equation ${ }^{7}$.

In order to examine the levels of competition in Serbian market, two hypotheses have been tested. Firstly, we apply the Panzar-Rosse model to the banking sector as a whole, in order to determine whether it exhibits monopolistic competition as it resulted in the above mentioned studies. Secondly, on the subset of the largest banks the level of competiveness is tested by using again the $\mathrm{H}$-statistics from the Panzar-Rosse model, to gain insight into the key market players' behaviours and to examine whether the players collude while setting the prices (i.e. whether they exhibit collusive oligopoly behaviour).

The contribution of this paper is therefore twofold. Firstly, this is the first paper that uses the non-structural approach to empirically analyse the competitiveness of Serbian banking sector over the last decade. ${ }^{8}$ Secondly, as opposed to other empirical studies, which mostly use price equation or a scaled revenue function, this paper uses an unscaled revenue function along with additional information about $\operatorname{costs}^{9}$ and market equilibrium to allow meaningful interpretations in line with the recent literature findings.

7 This conclusion raises question about robustness of the results of a number of banking competition studies Shaffer (1982a, 2004a), Nathan and Neave (1989), Molyneux et al. (1996), De Bandt and Davis (2000), Bikker and Haaf (2002), Claessens and Laeven (2004), Yildirim and Philippatos (2007), Schaeck et al. (2009), Coccorese (2009) among others.

8 Serbian banking industry has been rarely examined in the literature. Delis (2010) included Serbia in measuring the competitive conditions of Central and Eastern European banking systems, using data from period 1999-2006. However, from 2006 Serbian banking sector undergo significant structural changes which provide support for the analysis (separating Montenegro as independent country, state ownership decreased over time and economic crisis started in 2008 has been staggering the banking sector influencing the level of competition among banks).

${ }^{9}$ We also include additional risk factors among the control variables. 
Babić A. et al.: Testing for Competition in Serbian Banking Industry: the...

The rest of the paper is organized as follows. In order to provide intuition about the structure of Serbian banking market and highlight its similarities to other countries in the region, the next section provides a short overview of banking markets in Central and Eastern Europe (CEE) countries ${ }^{10}$. Section III contains a brief review of the Panzar-Rosse model and discusses the econometric methodology. Data and results from the panel estimation of competitiveness of Serbian banking sector are presented in Section IV. Final section concludes and discusses policy implications of the results. Appendix describes variables used in the empirical exercise.

\section{Banking sectors across Central and Eastern Europe}

The financial systems of CEE countries are dominated by the banking sectors. The development of market system over the past two decades was coupled with the increase in banking sector competition in transition economies (see e.g. Avdasheva et al. 2007). The perceived need for widening of the client base provided a strong "pull" factor for FDIs in banking sector (Konopielko, 1999). Foreign owned banks entry had a large impact on shaping the financial systems in transition countries. The banking sectors in these countries are closely related in terms of: dominant presence of foreign owned banks, greater market consolidation compared to developed countries, rapid credit growth experienced prior to the financial crisis and recent bank deleveraging.

The availability of domestic sources followed the increase in total amount of loans in all countries. Despite differences in the levels of financial developments across countries, measured in outstanding loans and deposits, the gaps between the two are decreasing implying increased resilience of domestic banking sectors to potential negative external shocks. This is especially true for the countries with high savings rates (e.g. Czech Republic and Slovak Republic), where domestic deposits are higher than outstanding loans.

CEE banking sectors are segmented and have large numbers of domestic banks. In all of these countries banking sectors are dominated by the small number of banks. The largest ten banks comprise more than $70 \%$ of assets in all of the countries (except Poland 60\%, which has the largest number of banks). Standard measures (e.g. $\mathrm{HHI}$ ) of conduct suggest low level of

\footnotetext{
${ }^{10}$ For the purposes of this paper, the following countries were taken into consideration: Bulgaria, Croatia, the Czech Republic, Hungary, Poland, Romania, Slovakia and Serbia.
} 
Babić A. et al.: Testing for Competition in Serbian Banking Industry: the...

concentration in all CEE countries. Previous studies typically rejected the market imperfections as the focus was on the entire banking sector, i.e. they included all banks in analysis. The main findings excluded bipolar cases of monopoly and perfect competition and usually implied monopolistic competition. The finding for the entire banking system is not surprising, given that a large number of banks compete on different segments of the market. However, as argued above, the conduct may be far less competitive than the concentration measures would suggest as profit maximization motive might stimulate the collusion among the largest banks. Therefore, the paper tests whether this is true for the subset of the largest banks, whose behaviour, given their relative size and set of services that they offer, should be closer to bipolar cases. It is hoped that the similarity among the CEE banking systems presented here will support the generalization of the results of these analysis.

The profitability of banking sectors in CEE is negatively affected by the high level of non-performing loans (NPL). In particular, the return on equity is the highest in Slovakia, Czech Republic and Poland, countries with lower levels of NPLs. The CEE banking sectors differ by the operational efficiency, which is highest in the Czech, Croatian and Slovak markets. The level of equity to assets is particularly high among all CEE banks, most notably in Serbia and Croatia.

Table 1. Key Banking Sector indicators in selected CEE countries in 2012

\begin{tabular}{|l|c|c|c|c|c|c|c|c|}
\hline & Bulgaria & Croatia & $\begin{array}{c}\text { Czech } \\
\text { Republic }\end{array}$ & Hungary & Serbia & Poland & Romania & Slovakia \\
\hline $\begin{array}{l}\text { Number of } \\
\text { Commercial } \\
\text { Banks }\end{array}$ & 31.0 & 33.0 & 43.0 & 44.0 & 29.0 & 69.0 & 30.0 & 24.0 \\
\hline $\begin{array}{l}\text { Largest 10 } \\
\text { Banks Share } \\
\text { in Total } \\
\text { Assets (\%) }\end{array}$ & 77.0 & 92.0 & 78.0 & 75.0 & 71.0 & 60.0 & 70.0 & 85.0 \\
\hline $\begin{array}{l}\text { Outstanding } \\
\text { loans (\% of } \\
\text { GDP) }\end{array}$ & 70.8 & 71.7 & 84.6 & 45.8 & 82.8 & 46.7 & 38.4 & 43.0 \\
\hline $\begin{array}{l}\text { Outstanding } \\
\text { deposits (\% } \\
\text { of GDP) }\end{array}$ & 63.2 & 64.1 & 94.6 & 37.7 & 49.5 & 39.8 & 33.5 & 45.0 \\
\hline $\begin{array}{l}\text { Return on } \\
\text { Equity (\%) }\end{array}$ & 5.6 & 7.0 & 14.7 & -2.5 & 0.2 & 12.2 & 1.2 & 15.0 \\
\hline $\begin{array}{l}\text { Net } \\
\text { Revenues } \\
\text { IAssets (\%) }\end{array}$ & 5.0 & 3.9 & 3.6 & 3.9 & 6.3 & 4.4 & 4.8 & 3.9 \\
\hline $\begin{array}{l}\text { Cost/Income } \\
\text { (\%) }\end{array}$ & 50.6 & 47.8 & 45.0 & 62.2 & 61.3 & 51.0 & 55.0 & 48.8 \\
\hline $\begin{array}{l}\text { EquitylAsset } \\
\text { s\%) }\end{array}$ & 10.3 & 13.8 & 6.8 & 10.9 & 16.0 & 8.6 & 8.4 & 11.0 \\
\hline $\begin{array}{l}\text { Non- } \\
\text { Performing } \\
\text { to Total } \\
\text { Gross Loans } \\
\text { (\%) }\end{array}$ & 16.9 & 13.2 & 5.1 & 15.8 & 19.0 & 8.4 & 16.8 & 5.3 \\
\hline
\end{tabular}

Source: International Monetary Fund International Financial Statistics, World Bank World Development Indicators, National Central Banks and Authors' Calculations. 
Babić A. et al.: Testing for Competition in Serbian Banking Industry: the...

\section{Modelling strategy}

This section begins with a brief summary of the Panzar and Rosse (1987) model used to determine the type of market structure in Serbian banking industry. The second subsection provides more details on the econometric methodology used in the empirical exercise.

\subsection{The Panzar and Rosse model}

This section briefly outlines the Panzar and Rosse (1987) model. The model aims to discriminate between oligopolistic, competitive and monopolistic markets. The test statistic (called $\mathrm{H}$ statistics) is derived from a reduced-form revenue equation of the bank and used to measure the market behaviour of banks.

The test is developed in accordance with the general banking market model, which, by maximizing the profits of individual banks and the whole banking market simultaneously, provides the output and the number of banks in equilibrium. On individual level, for a bank $i$, marginal revenue equals marginal costs:

$$
R_{i}^{\prime}\left(x_{i}, n, z_{i}\right)=C_{i}^{\prime}\left(x_{i}, w_{i}, t_{i}\right)
$$

where $R_{i}$ stands for revenues and $C_{i}$ for costs of bank $i$, the prime refers to the first derivative, i.e. the marginal values, $x_{i}$ is the output of bank $i, n$ is the number of banks in the market, $w_{i}$ is a vector of factor input prices of bank $i$ and $z_{i}$ and $t_{i}$ are vectors of exogenous variables that shift bank's revenue and cost functions, respectively. At the market level, zero profit constraint holds:

$$
R_{i}^{*}\left(x^{*}, n^{*}, z_{i}\right)=C_{i}^{*}\left(x^{*}, w, t\right)
$$

where $x^{*}$ and $n^{*}$ denote the output and the number of banks, in equilibrium. Market power is measured as the value of changes in equilibrium revenues due to changes in banks' factor input prices. Therefore, the measure of competition used in the empirical exercise, the $\mathrm{H}$-statistic, is defined as the sum of the elasticities of the reduced-form revenues with respect to factor prices (labour, capital and interest costs).

$$
H=\sum_{k=1}^{m} \partial R_{i}^{*} / \partial w_{k_{i}} \cdot w_{k_{i}} / R_{i}^{*}
$$


Babić A. et al.: Testing for Competition in Serbian Banking Industry: the...

where $m$ is the number of input factors. Note here that in the empirical exercise $\mathrm{H}$ statistics is obtained as the sum of the estimated revenue elasticities to changes in labour, capital and interest costs (in other words as the sum of their coefficients, for more details see the following subsection).

Panzar and Rosse examined models for monopoly, monopolistic competition, perfect competition and conjectural variation oligopoly. In the case of monopoly an increase in input prices increases marginal costs, decreases equilibrium output, and, consequently, reduces revenues, which yield a nonpositive value of $\mathrm{H}$. In other three cases for an industrial market it is assumed that revenue functions of banks depend upon the decisions of their competitors and that these decisions result in positive values of $H$. The intuition behind this result lies in comparative static properties of the Chamberlinian equilibrium, where banks produce more output which pushes price down, below the optimal level for each individual bank. For monopolistic competition it can be shown that $\mathrm{H}$ is less than 1 . The limit case of the monopolistic competition model is perfect competition, where it is assumed that banks' products are perfect substitutes. Increase in input prices raises both marginal and average costs altering the optimal output of individual firms, while exit of some firms increases the demand, raising the prices and revenues which results in the values of $\mathrm{H}$ equal to 1 . The oligopoly case is analysed using the conjectural variations, where it is shown that strategic interactions among limited number of banks provide positive values of $\mathrm{H}$. In special cases of perfect cartel or strong oligopoly collusion, $\mathrm{H}$ is a nonpositive number.

The Chamberlinian equilibrium model also provides the relationship between $\mathrm{H}$ (explaining the market behaviour) and the number of banks (explaining the market structure). The model is based on free entry of banks and as a result it gives both the output level and the equilibrium number of banks. Panzar and Rosse (1987) combined two theoretical properties of $\mathrm{H}$ statistics to point out that there is a positive relationship between $\mathrm{H}$ and the number of banks, or in other words, inverse relationship between $\mathrm{H}$ and the concentration of banking market. This follows from the fact that $\mathrm{H}$ is an increasing function of the demand elasticity (Jukka Vesala, 1995), and the property of elasticity, which claims that $\mathrm{H}$ is a non-decreasing function of the number of rival banks. Therefore, the magnitude of $\mathrm{H}$ can be perceived as the measure of market competition.

In order to correctly interpret values of $\mathrm{H}$-statistics, it is important to examine whether the market is in equilibrium. This is done by replacing revenues with return on assets (ROA) as the dependent variable in a P-R reduced-form revenue equation retaining the same explanatory variables (for early application see Shaffer, 1982). H-statistics obtained from that equation explains the relationship between input prices and revenues in free-entry 
Babić A. et al.: Testing for Competition in Serbian Banking Industry: the...

equilibrium. As in equilibrium state ROA between firms should be equal due to market forces and not affected with changes in input prices, the null hypothesis of market equilibrium is rejected if $\mathrm{H}$-statistic from ROA equation is not significantly different from 0 . This property is furthermore used to supplement tests of $\mathrm{H}$-statistic in determination of the competitiveness of banking market.

\subsection{Econometric methodology}

Before proceeding to competition analysis, this section reviews econometric methodology. In order to adjust the Panzar and Rosse (1987) model for banking industry, we use an additional assumption that banks are primarily considered as financial intermediaries. Since Bikker et al. (2012) recently showed that choice of bank's performance measure (dependent variable) may impact the obtained results and that neither scaled revenue function nor price equation would yield a valid measure for competitive conduct, this paper uses the non-scaled reduced-form revenue function. In order to allow for non-linear effects, the log specification was applied on panel data. The empirical model can be written as follows:

$$
\begin{aligned}
& \ln R E V_{i t} \\
& \quad=\alpha+\beta \ln P L_{i t}+\gamma \ln P K_{i t} \\
& +\delta \ln P F_{i t}+\theta_{1} A_{i t}+\theta_{2} O_{i t} \\
& +\theta_{3} \ln L_{i t} \\
& \\
& +\theta_{4} \ln E_{i t}+\theta_{5} \ln R_{i t}+\theta_{6} \ln O F F_{i t}+\theta_{7} \ln D_{i t} \\
& +\theta_{8} \ln F+\varepsilon_{i t}
\end{aligned}
$$

where $R E V$ stands for unscaled revenue which can be total revenue $(T R)$ or just income revenue $(I R), P L$ is the average labour cost per employee, $P K$ is the ratio of amount of capital expenditure and accumulated depreciation over fixed assets, $P F$ is the ratio of interest costs over total deposits, $A$ is the total asset market share, $O$ is the ratio of other revenue over total revenue, $L$ is the ratio of total loans over total assets, $E$ is the ratio of total equity over total assets, $R$ is the ratio of loan loss provisions over total assets, OFF is the ratio of total off-balance sheet items over total assets, $D$ is the ratio of total deposits over total assets and $F$ is the ratio of fixed assets over total assets (see Appendix for more details on the definition of variables the sources of the data). Total equity over total assets ratio $E$ and loan loss provision over total 
Babić A. et al.: Testing for Competition in Serbian Banking Industry: the...

asset ratio $R$ are not used together in equations, since they both present controls for the bank's level of risk.

Estimates are obtained using the feasible generalized least squares method in order to control for heteroskedasticity problem which arises from the use of non-scaled revenues as a dependent variable (for detail discussion see Bikker et al. 2012). H statistics is calculated as the sum of elasticities of revenues to the changes in input factor prices, i.e. prices of labour, capital and interest costs, $H=\beta+\gamma+\delta$.

In order to examine whether the banking market is in free-entry equilibrium (following Bikker et al. 2012), REV is replaced by the return on assets (ROA), retaining all explanatory variables the same:

$$
\begin{aligned}
& \ln R O A_{i t} \\
& =\alpha+\beta \ln P L_{i t}+\gamma \ln P K_{i t} \\
& +\delta \ln P F_{i t}+\theta_{1} A_{i t}+\theta_{2} O_{i t} \\
& \\
& +\theta_{3} \ln L_{i t}+\theta_{4} \ln E_{i t}+\theta_{5} \ln R_{i t}+\theta_{6} \ln O F F_{i t} \\
& +\theta_{7} \ln D_{i t}+\varepsilon_{i t}
\end{aligned}
$$

\section{Data and results}

This section presents the results from the analysis of competition in Serbian banking industry. In the used sample, banking sector in Serbia consisted of 31 banks. ${ }^{11}$ Each bank had asset share lower than 15\%, which generally implies a low market concentration. Some announcements have been made recently, about potential mergers and acquisitions of some banks with mixture of state and public ownership structure yielding to consolidation of Serbian financial sector. These changes in market structure could significantly affect the banking sector and provide further support for investigation of current and future levels of competitiveness among banks.

Sample for the analysis covers banks from Serbian banking sector in the period of 2004-2012. In years after 2012, several banks defaulted or left the

\footnotetext{
${ }^{11}$ In recent period, there were bankruptcies of two non-systematically important stateowned banks.
} 
Babić A. et al.: Testing for Competition in Serbian Banking Industry: the...

market, while during that period only one bank entered the market, so the sample is rather stable in terms of the number of banks which is important to keep the panel of data balanced. Therefore, the paper considered 30 banks that were present during the entire period. Majority of the data was gathered from bank's audited balance sheets and income statements published at the National Bank of Serbia's website, while the data on capital expenditure and employee numbers were obtained from the Serbian Statistical Office.

The paper adopted a two-step approach to analyse the competition in Serbian banking sector. Firstly, the empirical model was applied to the sample of all banks. Secondly, the same empirical procedure was used on a subset of large banks.

Table 2, Table 3 and Table 4 show the estimated parameters of P-R model for the equation where dependent variables are total revenue, interest revenue and ROA, respectively. The sample covers all banks in Serbia.

Table 2. Estimated elasticities of revenue to changes in factor prices, sample all banks

\begin{tabular}{|c|c|c|c|c|}
\hline Variable & Coefficient & Standard Error & $\mathbf{z}$ & p-value \\
\hline $\ln (\mathrm{PL})$ & 0.0648 & 0.0173 & 3.74 & 0.0000 \\
\hline $\ln (\mathrm{PK})$ & -0.0179 & 0.0060 & -3.00 & 0.0030 \\
\hline $\ln (\mathrm{PF})$ & 0.0976 & 0.0383 & 2.55 & 0.0110 \\
\hline A & 18.8438 & 0.8264 & 22.8 & 0.0000 \\
\hline $\mathrm{O}$ & 0.8092 & 0.1396 & 5.80 & 0.0000 \\
\hline $\ln (L)$ & 1.1517 & 0.1745 & 6.60 & 0.0000 \\
\hline $\ln (E)$ & -0.3226 & 0.0715 & -4.51 & 0.0000 \\
\hline $\ln (\mathrm{OFF})$ & 0.3003 & 0.0464 & 6.47 & 0.0000 \\
\hline $\ln (D)$ & 0.1250 & 0.0260 & 4.80 & 0.0000 \\
\hline $\ln (F)$ & -0.2867 & 0.0363 & -7.89 & 0.0000 \\
\hline const. & 13.0944 & 0.2453 & 53.38 & 0.0000 \\
\hline Wald test & H-statistic & & $x^{2}$ & p-value \\
\hline $\ln (P L)+\ln (P K)+\ln (P F)=0$ & \multirow{2}{*}{0.1445} & & 11.96 & 0.0000 \\
\hline $\ln (P L)+\ln (P K)+\ln (P F)=1$ & & & 391.97 & 0.0000 \\
\hline
\end{tabular}


Babić A. et al.: Testing for Competition in Serbian Banking Industry: the...

Table 3. Estimated elasticities of interest revenue to changes in factor prices, sample all banks

\begin{tabular}{|c|c|c|c|c|}
\hline Variable & Coefficient & Standard Error & $\mathbf{z}$ & p-value \\
\hline $\ln (P L)$ & 0.0662 & 0.0168 & 3.94 & 0.0000 \\
\hline $\ln (\mathrm{PK})$ & -0.0154 & 0.0054 & -2.83 & 0.0050 \\
\hline $\ln (P F)$ & 0.0408 & 0.0366 & 1.12 & 0.2650 \\
\hline A & 18.6632 & 0.9621 & 19.40 & 0.0000 \\
\hline $\mathrm{O}$ & -1.7267 & 0.1418 & -12.17 & 0.0000 \\
\hline $\ln (L)$ & 1.1344 & 0.1711 & 6.63 & 0.0000 \\
\hline $\ln (E)$ & -0.2874 & 0.0694 & -4.14 & 0.0000 \\
\hline $\ln (\mathrm{OFF})$ & 0.2489 & 0.0452 & 5.51 & 0.0000 \\
\hline $\ln (D)$ & 0.0806 & 0.0240 & 3.36 & 0.0010 \\
\hline $\ln (F)$ & -0.2076 & 0.0343 & -6.05 & 0.0000 \\
\hline const. & 13.5149 & 0.2337 & 57.82 & 0.0000 \\
\hline Wald test & $\mathrm{H}$-statistic & & $x^{2}$ & $p$-value \\
\hline $\ln (P L)+\ln (P K)+\ln (P F)=0$ & \multirow{2}{*}{0.0916} & & 5.32 & 0.0211 \\
\hline $\ln (P L)+\ln (P K)+\ln (P F)=1$ & & & 394.15 & 0.0000 \\
\hline
\end{tabular}

Table 4. Estimated elasticities of ROA to changes in factor prices, sample all banks

\begin{tabular}{|c|r|r|c|r|}
\hline Variable & Coefficient & Standard Error & \multicolumn{1}{c|}{ z } & p-value \\
\hline $\operatorname{In}(\mathrm{PL})$ & 0.0083 & 0.0022 & 3.78 & 0.0000 \\
\hline $\operatorname{In}(\mathrm{PK})$ & 0.0019 & 0.0007 & 2.60 & 0.0090 \\
\hline $\operatorname{In}(\mathrm{PF})$ & -0.0091 & 0.0046 & -1.99 & 0.0460 \\
\hline $\mathrm{O}$ & -0.1701 & 0.0316 & -5.39 & 0.0000 \\
\hline $\ln (\mathrm{L})$ & -0.0890 & 0.0220 & -4.04 & 0.0000 \\
\hline $\ln (\mathrm{E})$ & -0.0534 & 0.0093 & -5.77 & 0.0000 \\
\hline $\operatorname{In}(\mathrm{OFF})$ & 0.0148 & 0.0056 & 2.64 & 0.0080 \\
\hline $\operatorname{In}(\mathrm{D})$ & 0.0095 & 0.0081 & 1.17 & 0.2420 \\
\hline $\mathbf{W a l d}$ test & H-statistic & & $\mathbf{X}^{2}$ & $\mathbf{p}$-value \\
\hline $\ln (\mathrm{PL})+\ln (\mathrm{PK})+\ln (\mathrm{PF})=0$ & 0.0011 & & 0.04 & 0.8440 \\
\hline
\end{tabular}

The results in Table 2 show that $\mathrm{H}=0.1445$ and Wald test rejects the hypotheses of competition $(\mathrm{H}=1)$ and of monopoly $(\mathrm{H}=0)$, which means that 
Babić A. et al.: Testing for Competition in Serbian Banking Industry: the...

$0<\mathrm{H}<1$. An unscaled revenue function generally requires additional information about costs and market equilibrium to allow for meaningful interpretations. Therefore, the result is additionally confirmed by the equation with interest income as a dependent variable. However as $\mathrm{H}$ is positive, rejecting hypotheses of perfect competition and monopoly based on two previous tests does not imply specific market conduct. It is still possible that banks may be behaving as monopolistic competitors, competitive firms that are not yet in long-run equilibrium or even as long-run competitive firms with constant average cost curves (Bikker et al. 2012). Therefore, the paper proceeds to test the null hypothesis of $\mathrm{H}_{\mathrm{ROA}}=0$. By failing to reject this, the data suggests that the market is in equilibrium and implies monopolistic competition.

These results are in line with the literature and confirm the first starting hypothesis of the paper. Given that a large number of banks offer different products and compete on different segments of the market the finding is not surprising. To further examine competitiveness among key market participants, paper next focuses on the subset of large banks. The criterion used for the selection of banks was the asset share above the $5 \%$. $^{12}$

Table 5, Table 6 and Table 7 show the estimates of the coefficients for the subset of large banks, where dependent variables are total revenue, interest revenue and $\mathrm{ROA}$, respectively. In the last row of Table $5, \mathrm{H}$ statistics is negative (-0.3246) and highly statistically significant suggesting the monopoly or in this case oligopoly with perfect collusion. This result is further confirmed by the equation of income revenue where $\mathrm{H}$ statistics equals -0.4264 . Market equilibrium test additionally supports previous findings as $\mathrm{H}_{\mathrm{ROA}}$ is negative ($0.0190)$ and highly statistically significant. The fact that $H_{R O A}$ is negative requires more detailed explanation. This does not indicate that market is not in a structural equilibrium. As theory suggests, if accounting profits are sufficiently correlated with economic profits, then $\mathrm{H}_{\mathrm{ROA}}=0$ should be observed. However, under imperfect competition, economic profits are positive and the observed accounting ROA may vary across firms or over time (e.g. asymmetric Cournot oligopoly). In particular, ROA may respond to input prices under imperfect competition, so $\mathrm{H}_{\mathrm{ROA}}$ needs not to be equal zero (and in general would not see Bikker et al. 2012) even if the market is in structural equilibrium. Therefore all three findings are consistent and imply that large banks exhibit monopoly or perfect collusive oligopoly behaviour.

12 This reduced the sample to 8 "large" banks. Their share in total banking sector assets is above $65 \%$ (in 2012). 
Babić A. et al.: Testing for Competition in Serbian Banking Industry: the...

Table 5. Estimated elasticities of revenue to changes in factor prices, sample large banks

\begin{tabular}{|c|r|r|c|c|}
\hline Variable & Coefficient & Standard Error & z & p-value \\
\hline $\operatorname{In}(\mathrm{PL})$ & -0.0421 & 0.0306 & -1.38 & 0.1680 \\
\hline $\operatorname{In}(\mathrm{PK})$ & -0.0316 & 0.0050 & -6.34 & 0.0000 \\
\hline $\operatorname{In}(\mathrm{PF})$ & -0.2509 & 0.1295 & -1.94 & 0.0530 \\
\hline $\mathrm{A}$ & 14.3534 & 1.7724 & 8.10 & 0.0000 \\
\hline $\mathrm{O}$ & 0.7068 & 0.2362 & 2.99 & 0.0030 \\
\hline $\operatorname{In}(\mathrm{L})$ & -1.1261 & 0.7296 & -1.54 & 0.1230 \\
\hline $\operatorname{In}(\mathrm{R})$ & 0.1299 & 0.1182 & 1.10 & 0.2720 \\
\hline $\operatorname{In}(\mathrm{OFF})$ & 0.4077 & 0.0510 & 8.00 & 0.0000 \\
\hline $\operatorname{In}(\mathrm{D})$ & 0.1367 & 0.0485 & 2.82 & 0.0050 \\
\hline $\operatorname{In}(\mathrm{F})$ & -0.3027 & 0.0755 & -4.01 & 0.0000 \\
\hline $\operatorname{const}$ & 13.7410 & 0.6613 & 20.78 & 0.0000 \\
\hline $\mathbf{W a l d}$ test & H-statistic & & $\mathbf{X}^{2}$ & $\mathbf{p}$-value \\
\hline $\ln (\mathrm{PL})+\ln (\mathrm{PK})+\ln (\mathrm{PF})=0$ & -0.3246 & & 6.53 & 0.0106 \\
\hline
\end{tabular}

Table 6. Estimated elasticities of interest revenue to changes in factor prices, sample large banks

\begin{tabular}{|c|c|c|c|c|}
\hline Variable & Coefficient & Standard Error & $\mathbf{z}$ & p-value \\
\hline $\ln (P L)$ & -0.0108 & 0.0346 & -0.31 & 0.7540 \\
\hline $\ln (\mathrm{PK})$ & -0.0255 & 0.0047 & -5.38 & 0.0000 \\
\hline $\ln (P F)$ & -0.3801 & 0.1296 & -2.93 & 0.0030 \\
\hline A & 14.8560 & 1.8210 & 8.16 & 0.0000 \\
\hline $\mathrm{O}$ & -2.1626 & 0.2536 & -8.53 & 0.0000 \\
\hline $\ln (L)$ & 0.2428 & 0.1156 & 2.10 & 0.0360 \\
\hline $\ln (\mathrm{R})$ & 0.3114 & 0.0596 & 5.23 & 0.0000 \\
\hline $\ln (\mathrm{OFF})$ & 0.1002 & 0.0475 & 2.11 & 0.0350 \\
\hline $\ln (D)$ & -0.2146 & 0.0786 & -2.73 & 0.0060 \\
\hline $\ln (F)$ & 14.3091 & 0.5964 & 23.99 & 0.0000 \\
\hline const. & -0.0108 & 0.0346 & -0.31 & 0.7540 \\
\hline Wald test & H-statistic & & $x^{2}$ & p-value \\
\hline $\ln (P L)+\ln (P K)+\ln (P F)=0$ & -0.4164 & & 10.66 & 0.0011 \\
\hline
\end{tabular}


Babić A. et al.: Testing for Competition in Serbian Banking Industry: the...

Table 7. Estimated elasticities of ROA to changes in factor prices, sample large banks

\begin{tabular}{|c|r|r|c|r|}
\hline Variable & Coefficient & Standard Error & \multicolumn{1}{c|}{$\mathbf{z}$} & p-value \\
\hline $\ln (\mathrm{PL})$ & -0.0078 & 0.0017 & -4.61 & 0.0000 \\
\hline $\ln (\mathrm{PK})$ & 0.0002 & 0.0007 & 0.27 & 0.7890 \\
\hline $\ln (\mathrm{PF})$ & -0.0114 & 0.0059 & -1.95 & 0.0520 \\
\hline 0 & -0.1913 & 0.0202 & -9.46 & 0.0000 \\
\hline $\ln (\mathrm{L})$ & -0.4111 & 0.0395 & -10.41 & 0.0000 \\
\hline $\ln (\mathrm{R})$ & -0.0310 & 0.0049 & -6.35 & 0.0000 \\
\hline $\ln (\mathrm{OFF})$ & 0.0176 & 0.0039 & 4.46 & 0.0000 \\
\hline $\ln (\mathrm{D})$ & 0.0094 & 0.0039 & 2.39 & 0.0170 \\
\hline $\ln (\mathrm{F})$ & -0.0159 & 0.0036 & -4.45 & 0.0000 \\
\hline $\mathbf{W a l d}$ test & H-statistic & & $\mathbf{X}^{2}$ & $\mathbf{p}$-value \\
\hline $\ln (\mathrm{PL})+\ln (\mathrm{PK})+\ln (\mathrm{PF})=0$ & -0.0190 & & 8.58 & 0.0034 \\
\hline
\end{tabular}

\section{Conclusions and policy implications}

This paper empirically analyses the levels of competition in Serbian banking sector over the last decade. Panel estimates are used to empirically test Panzar-Rosse model for the whole banking sector and for the subset of eight largest banks.

These results suggest that the level of competition differs depending on the number and size of the observed banks. For the entire market, which is characterized by large number of banks, the estimated relationship between revenues and costs is in line with monopolistic competition among banks. This implies that the whole market is producing more output with lower price than it would be in individual optimal case for each bank. This result can be explained by product differentiation since banks tend to differ from each other in respect of the quality of their products, although the core of their business is quite homogeneous. In case of large banks, results indicate the existence of monopoly or oligopoly with perfect collusion, which can in some cases include short-run competition, but not the long-run one. Theoretical implication of these findings may be that large banks offer the amount of products that allows them to maximize their products at optimal levels of individual profit maximization or cooperate in setting up the prices and supply levels, in both cases serving as price makers. Further investigation of potential collusion among large banks remains beyond the scope of this paper. 
Babić A. et al.: Testing for Competition in Serbian Banking Industry: the...

The policy implications of these results are several. Firstly, the finding of large banks monopolistic or oligopolistic behaviour has important implications for the efficiency of monetary policy, given that bank's interest rates in more competitive markets respond more strongly to changes in market interest rates (see for example, Van Leuvenstein et al, 2011). Therefore, measures to enhance competition in the Serbian banking sector will tend to render the monetary policy transmission mechanisms more effective. ${ }^{13}$

Secondly, under the "competition-stability" view (see Berger et al. 2009) more market power in the loan market may result in higher bank risk as the higher interest rates charged to loan customers make it harder to repay loans, exacerbate moral hazard and adverse selection problems. Therefore, central banks in countries facing non-competitive markets should further enhance both macro- and micro-prudential framework to reduce systematic risks steaming from loan portfolio risk.

Thirdly, the results suggest that large banks offer their products at suboptimal market levels or cooperate in setting up the prices and supply levels, in both cases serving as price makers. Therefore, more has to be done in terms of enhancing competitiveness of banking sector, as the empirical literature shows that the fall of margins is compatible with higher levels of competition. Moreover, higher level of competition forces banks to weight factor productivity more, which is a prerequisite for sustainable growth. However, the regulators need to be cautious in setting up the measures that stimulate competition given that increase in market power and concentration can sometimes reduce the interest rate risk, credit risk, and operating costs (see Maudos and De Guevara, 2007).

Finally, similarities between the CEE banking systems presented in Section 2 support the generalization of our results and the policy implications to other countries in the region.

The empirical findings indicate that competitive behaviour of banks may be explained by factors other than the number of banks and levels of concentration in the banking sector. However, in interpreting results one has to be aware of certain limitations of Panzar and Rosse model. Firstly, the P-R model considers banks as financial intermediaries which produce single product (De Bandt and Davis, 2000), generating interest income using inputs such as deposits, capital and labour. Differentiation of products could be accepted if model results in a monopolistic competition for banking market

13 Further research should focus on estimating the impact of banking sector competitiveness on interest rate pass-through in Serbia. 
Babić A. et al.: Testing for Competition in Serbian Banking Industry: the...

(Gelos and Roldos, 2004). Secondly, the model assumes the same cost function for all banks, where higher input prices do not result in a higherquality service or higher revenues. This may lead to a bias in estimated $\mathrm{H}$ statistics, although that bias is lower if null hypothesis of competitive market is rejected (Molynuex et al. 1996). Thirdly, P-R model has a static nature. This problem is partially overcome by using panel data, but examination of competition in the long-run would require a dynamic approach of observing changes in $\mathrm{H}$-statistic over time.

\section{References}

Allen F. and Gale D. (2004). Competition and Financial Stability. Journal of Money, Credit, and Banking 36: 453-480.

Avdasheva, S., Shastitko, A., and Kuznetsov, B. (2007). Competition and Industrial Organisation in Transition Markets: What Can We Derive from Empirical Studies?. Post-Communist Economies, 19(1), 17-33.

Berger A. N. and Hannan T. H. (1998). The efficiency cost of market power in the banking industry: A test of the 'quiet life' and related hypotheses. Review of Economics and Statistics 8: 454-465.

Berger A. N., Klapper L. F. and Ariss R. T. (2009). Bank competition and financial stability. Journal of Financial Services Research, 35(2): 99-118.

Bikker J. A. and Haaf K. (2002). Competition, concentration and their relationship: An empirical analysis of the banking industry. Journal of Banking and Finance 26: 2191-2214.

Bikker J. A. and Spierdijk L. (2008). How Banking Competition Changed over Time. Working Papers 08-04, Utrecht School of Economics

Bikker J. A., Shaffer S. and Spierdijk L. (2012). Assessing competition with the Panzar-Rosse model: The role of scale, costs, and equilibrium. Review of Economics and Statistics, 94(4): 1025-1044.

Botrić, V., and Slijepčević, S. (2008). Economic growth in South-eastern Europe: the role of the banking sector. Post-communist economies, 20(2), 253-262.

Bresnahan T. F. (1989). Empirical studies of industries with market power. Handbook of industrial organization, 2: 1011-1057.

Bruna, K. (2008). Monetary policy stabilisation, changes in the banking system and interest rate pass-through: the Czech Republic 1999-2006. Post-Communist Economies, 20(4), 413-429.

Claessens S. and Laeven L. (2004). What drives bank competition? Some international evidence. Journal of Money, Credit, and Banking 36: 563-583.

Coccorese P. (2009). Market power in local banking monopolies. Journal of Banking \& Finance 33: 1196-1210.

Collender R. N. and Shaffer S. (2003). Local bank office ownership, deposit control, market structure, and economic growth. Journal of Banking \& Finance 27: 2757.

De Bandt O. and Davis P. E. (2000). Competition, contestability and market structure in European banking sectors on the eve of EMU. Journal of Banking \& Finance, 24(6): 1045-1066. 
Babić A. et al.: Testing for Competition in Serbian Banking Industry: the...

De Jonghe O. and Vander Vennet R. (2008). Competition versus efficiency: What drives franchise values in European banking. Journal of Banking \& Finance 32: 1820-1835.

De Rozas L. G. (2007). Testing for competition in the Spanish banking industry: The Panzar-Rosse approach revisited. Banco de España Research Paper No. WP0726.

Delis M. D. (2010). Competitive conditions in the Central and Eastern European banking systems. Omega, 38(5): 268-274.

Gelos G. R. and Roldos J. (2004). Consolidation and market structure in emerging market banking systems. Emerging Markets Review, 5(1): 39-59.

Iwata G. (1974). Measurement of conjectural variations in oligopoly. Econometrica: Journal of the Econometric Society, 947-966.

Jayaratne J. and Strahan P. E. (1996). The finance-growth nexus: evidence from bank branch deregulation. Quarterly Journal of Economics 111: 639-670.

Konopielko, L. (1999). Foreign banks' entry into central and east European markets: motives and activities. Post-Communist Economies, 11(4), 463-485.

Levine R., Loayza N. V. and Beck T. (2000). Financial intermediation and growth: Causality and causes. Journal of Monetary Economics 46: 31-77.

Ljumović, I., Pavlović, V., \& Cvijanović, J. M. (2014). Two aspects of concentration in Serbian banking sector. Industrija, 42(3), 61-77.

Macit F. (2012). Recent evidence on concentration and competition in Turkish banking sector. Theoretical and Applied Economics, 8(8): 19.

Matthews K., Murinde V. and Zhao T. (2007). Competitive conditions among the major British banks. Journal of Banking \& Finance, 31(7): 2025-2042.

Maudos J. and De Guevara J. F. (2007). The Cost of Market Power in Banking: Social Welfare Loss vs. Cost Inefficiency. Journal of Banking \& Finance 31: 21032125.

Miljković, M. M., Filipović, S., \& Tanaskovic, S. (2013). Market concentration in the banking sector: Evidence from Serbia. Industrija, 41(2): 7-26.

Molyneux P., Thornton J. and Llyod-Williams M. D. (1996). Competition and market contestability in Japanese commercial banking. Journal of Economics and Business, 48(1): 33-45.

Nathan E. and Neave E. H. (1989). Competition and contestability in Canada's financial system: empirical results. Canadian Journal of Economics 3: 576-594.

Panzar J. C. and Rosse J. N. (1987). Testing for 'monopoly' equilibrium. Journal of Industrial Economics 35: 443-456.

Schaeck K., Cihak M. and Wolfe S. (2009). Are competitive banking systems more stable? Journal of Money, Credit, and Banking 41: 711-734.

Shaffer S and DiSalvo J. (1994). Conduct in a banking duopoly. Journal of Banking \& Finance 18: 1063-1082.

Shaffer S. (1982). A non-structural test for competition in financial markets. In Proceedings of a Conference on Bank Structure and Competition, Federal Reserve Bank of Chicago, 225-243.

Shaffer S. (1993). A test of competition in Canadian banking. Journal of Money, Credit, and Banking 25: 49-61.

Shaffer S. (1999). The competitive impact of disclosure requirements in the credit card industry. Journal of Regulatory Economics 15, 183-198.

Shaffer S. (2002). Conduct in a banking monopoly. Review of Industrial Organization 20: $221-238$. 
Babić A. et al.: Testing for Competition in Serbian Banking Industry: the...

Shaffer S. (2004). Patterns of competition in banking. Journal of Economics and Business, 56(4): 287-313.

Smith R. T. (1998). Banking Competition and Macroeconomic Performance. Journal of Money, Credit, and Banking 30: 793-815.

Van Leuvensteijn M., Bikker J. A., Van Rixtel A. A. R. J. M. and C. K. (2011), A new approach to measuring competition in the loan markets of the euro area. Applied Economics 43(23): 3155-3167.

Vesala J. (1995). Testing for competition in banking: behavioral evidence from Finland. Helsinki: Bank of Finland.

Weill L. (2013). Bank Competition in the EU: How Has It Evolved? Journal of International Financial Markets, Institutions and Money

Yildirim and George C. Philippatos. (2007). Competition and contestability in Central and Eastern European banking markets. Managerial Finance, 33(3): 195-209. 
Babić A. et al.: Testing for Competition in Serbian Banking Industry: the...

\section{Appendix}

Table 8. Description of the variables in the model

\begin{tabular}{|l|c|c|}
\hline Variable & Definition & Source \\
\hline TR & Total Revenue & $\begin{array}{c}\text { Income statement, Balance } \\
\text { Sheet, National Bank of Serbia }\end{array}$ \\
\hline IR & Interest Revenue & $\begin{array}{c}\text { Income statement, Balance } \\
\text { Sheet, National Bank of Serbia }\end{array}$ \\
\hline ROA & Net Income over Total Assets & $\begin{array}{c}\text { Income statement, Balance } \\
\text { Sheet, National Bank of Serbia }\end{array}$ \\
\hline PL & Labour Expense over Number of \\
Employees & $\begin{array}{c}\text { Income Statement, National Bank } \\
\text { of Serbia and Serbian Statistical } \\
\text { Office }\end{array}$ \\
PK & $\begin{array}{c}\text { Capital Expenditure and Accumulated } \\
\text { Depreciation over Fixed Assets }\end{array}$ & $\begin{array}{c}\text { Balance Sheet, National Bank of } \\
\text { Serbia and Serbian Statistical } \\
\text { Office }\end{array}$ \\
\hline PF & Anterest Expenses over Total Deposits & $\begin{array}{c}\text { Income statement, Balance } \\
\text { Sheet, National Bank of Serbia }\end{array}$ \\
\hline A & $\begin{array}{c}\text { Total Assets over Total Banking Market } \\
\text { Balance Sheet, National Bank of } \\
\text { Serbia }\end{array}$ \\
\hline O & Other Expenses over Total Revenue & $\begin{array}{c}\text { Income statement, National Bank } \\
\text { of Serbia }\end{array}$ \\
\hline L & Total Loans over Total Assets & $\begin{array}{c}\text { Balance Sheet, National Bank of } \\
\text { Serbia }\end{array}$ \\
\hline E & Total Equity over Total Assets & $\begin{array}{c}\text { Balance Sheet, National Bank of } \\
\text { Serbia }\end{array}$ \\
\hline R & Loan Loss Provisions over Total Assets & $\begin{array}{c}\text { Balance Sheet, National Bank of } \\
\text { Serbia }\end{array}$ \\
\hline OFF & Total Off-Balance Sheet Items over \\
D Total Assets & $\begin{array}{c}\text { Off-Balance Sheet, Balance } \\
\text { Sheet, National Bank of Serbia }\end{array}$ \\
\hline F & Total Deposits over Total Assets & $\begin{array}{c}\text { Balance Sheet, National Bank of } \\
\text { Serbia }\end{array}$ \\
\hline & Fixed Assets over Total Assets & $\begin{array}{c}\text { Balance Sheet, National Bank of } \\
\text { Serbia }\end{array}$ \\
\hline
\end{tabular}

